\title{
REVIEWS.
}

\section{ORGANISATION, STRATEGY AND TACTICS OF THE ARMY MEDICAL SERVICE IN WAR.}

By Lieut.-Colonel T. B. Nicholls, M.B., Ch.B. Late R.A.M.C. Second Edition. Baillière Tindall \& Cox. London. 1940. Price 15s. 0d.

Within four years the First Edition of Colonel Nicholl's book has been exhausted. The appearance of a second is a tribute to the value that has been placed upon his work, and to the need that was felt for information on all phases of medico-military duties.

In the second edition new sections appear. Chapters have been added on the transport of casualties by air, on the medical services of an anti-aircraft division, and an account is given of the Emergency Medical Services of the The Ministry of Health.

As regards transportation of casualties by air, Air-Commodore Glynn gave a short resumé of what has been done in the past, for instance, in Iraq, and after the Quetta earthquake. The section was written, possibly, at a time when the full importance from a surgical point of view of air ambulances in the Western Desert or the Near East had yet to be appreciated. It is a simple platitude to state that out there rapid and smooth transportation in case of head, chest and abdominal wounds would make the difference between survival and death; just as it did in the Waziristan campaign of 1937, when a man might be wounded at 6 a.m. in a frontier nullah, and be in hospital at Murree, 350 miles away, by lunch time.

Col. Lescher contributes the section on Medical Arrangements for Military Casualties at Home, and the material in these 80 pages is among the most informative and valuable in the book. The organisation of the E.M. Scheme is clearly explained, and the implications followed up very thoroughly. A study of these chapters promotes ready criticism of the scheme, which fortunately has no place in this notice. At the same time, the reader cannot fail to realise that, whatever may be the failings of the scheme, it has proved to be sufficiently elastic to permit its major conception radically and successfully to be amended. It was designed to work from the centre towards the periphery. The Dunkirk emergency compelled the line of approach to be in the reverse direction, whilst in the bombardment of London now going on, the line of evacuation is as originally designed. The scheme has stood up to the test, whatever else may be said about it, and it works.

The decision on the part of the author to retain the section devoted to Problems and Exercises is open to criticism. The most recent scheme, it appears, is dated 1937. The draft solutions, suitable as they were to the tactical situation as visualized three years ago, would not meet eventualities of war as we find it to-day. The most recently joined lieutenant, studying this section in these times, stands in some danger of thinking he is reading about the times of
Alexander. To the Reviewer it seems that the whole of this section might with advantage have been omitted. No substitution to meet the mechanised war of to-day, other than something tentative or speculative, would rightly be possible. Even now, the whole organisation of the medical services of the army is under constant review, and except for the rôle of Divisional Medical Units, that of other formations is liable to radical changes. To give point to this suggestion, there can be few, who would view the rôle of the C.C.S. with equanimity in a war in which either side may move 50 or more miles a day. The old C.C.S. organisation, with its Nursing Sisters, flower gardens, and potato patches, and no transport of its own, is as dead (or should be) as a Bearer Company, and perhaps not as useful as the latter were such a unit to be revived.

The chapter on "Useful Data" on check is very accurate, and changes are unimportant.

Whatever criticism may be levelled against the book in detail, its value to the Army Medical Officer remains. And not only should it be in the possession of all officers of the R.A.M.C., but it might with great advantage be on the library bookshelf of every E.M.S. Hospital.

\section{DISEASES OF THE DIGESTIVE SYSTEM.}

By Eugene Rosenthal. Pp. 394. Henry

Kimpton. 1940. Price 42s. Od.

This book deals with the pathology, diagnosis and treatment of diseases of the digestive organs but the subject matter is not viewed from the specialist's standpoint, rather it is written for the information of the general practitioner. The presentation of the subject is somewhat unusual in that a new type of picture is introduced which may be regarded as illustrating mental association. The shape, details, colours and lines of these pictures are easily retained and stored in the memory.

With reference to the subject-matter of the book there are five chapters devoted to diseases of the œesophagus, stomach and intestinal tract, liver and biliary tract, pancreas and the peritoneum. Regarding the treatment of cancer of the osophagus we feel that the author adopts a too pessimistic outlook stating that $\mathrm{X}$-ray treatment has brought temporary relief and surgical removal or attempts at once have so far not been promising. X-ray therapy in the treatment of this disease has yielded encouraging results and recently interesting experiences have been published regarding the surgery of cancer of the œsophagus. The author perpetrates the erroneous terminology in classifying a pulsion diverticulum as oesophageal rather than pharyngeal. We cannot subscribe to the view expressed that hæmatemesis and melæna should always be treated medically as there are distinct indications for surgical intervention. The author is of opinion that it is doubtful whether the liberal diet of Holmgrew and Meulengracht should be generally adopted. With regard to the diagnosis 
of carcinoma of the sternal gastroscopy is considered of undoubted value but we do not undenstand why the author states that it cannot be generally adopted. We note with satisfaction the advocacy of graded operations in the surgery of cancer of the colon.

A feature of this book is the excellent diagrams over which it is obvious that much trouble has been expended. Many of the diagrams are in colour which is an excellent aid to the memory. The book is beautifully produced and in that it embodies the results of many years experience both of clinical work and teaching it is to be recommended to all who desire an arresting volume dealing with diseases of the digestive system.

\section{PYE'S SURGICAL HANDICRAFT.}

Edited by Hamilton BaIley. 12th Edition. Pp. 595. Bristol: John Wright \& Sons, Ltd. London: Simpkin Marshall, Ltd. 1940. Price 21s. 0d.

Fifty-six years have elapsed since Walter Pye enriched medical literature by the publication of his book on Surgical Handicraft. The book was a great success and a second edition was published a year later. During subsequent years no less than 12 editions have appeared and this in itself is adequate proof of the value of this work. The present edition is edited by Hamilton Bailey who has elicited the help of a large number of contributors responsible for specific subjects.

The subject matter of the book is essentially practical containing valuable information which House Surgeons are continuously requiring. It may be said that this is a book which should be possessed and studied by every House Surgeon for thereby his efficiency would be markedly improved. The subjects covered are most comprehensive and precise practical details are supplied in each case. Chapters are devoted to the relationship of the House Surgeon to the pathological and radiological departments and with the nursing staff of a hospital and useful information is also given concerning hospital administration.

This book is strongly recommended as one of the best of its kind to all House Surgeons and to medical practitioners, knowing that they will find in it a wealth of knowledge regarding problems which are daily recurring.

\section{FORTHCOMING MEDICAL BOOK.}

OXFORD MEDICAL PUBLICATIONS.

"A Practical Manual of Diseases of the Chest," by Maurice Davidson, M.A., M.D., F.R.C.P. 2nd Edition. Pp. xiv +575 , with one coloured plate and 200 illustrations. Price 2 guineas net.

\section{Miscellaneous.}

This Section deals with New Drugs, Preparations, Surgical Instruments, etc. The description of each article is supplied by the Producer. Particulars regarding in sertions, which are free of cost, may be obtained from the Business Manager, Fellowship of Medicine and Post-Graduate Journal, 323, Grand Buildings, W.C.2.

SULPHANILAMIDE POWDER BOOTS - Recent articles in the medical press have described the use of Sulphanilamide Powder as a local Boots Pure Drug Co., Ltd. application in the treatment of wound infections. From 5 to $15 \mathrm{gm}$. of Sulphanilamide are incorporated into the depths of the wound at the time of debridement to prevent the spread of bacteria in and around the wound, the amount of powder used depending on the extent of the trauma. The results so far obtained have been very encouraging.

Sulphanilamide Powder (Boots) is supplied in cartons containing 10 packets of 15 gm., 7s. 6d. Subject to 15 per cent. discount to the medical profession. Literature and a sample of this product may be obtained on application to Medical Information Dept., Boots Pure Drug Co., Ltd., Station Street, Nottingham.
H. K. LEWIS \& Co. Ltd.

MEDIGAL PUBLISHERS AND BOOKSELLERS I36 GOWER ST. LONDON, W.C.I

(Adjoining University College and Hospital)

Telephone: EUSton 4282 (5 lines)

Telegrams: Publicavit, Westcent, London

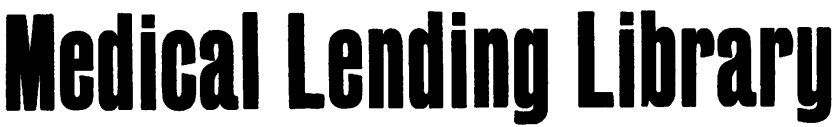

ANNUAL SUBSCRIPTION from ONE GUINEA

FOR THE CONVENIENCE OF POST-GRADUATE STUDENTS SHORT PERIOD SUBSCRIPTIONS ARE ARRANGED-FOR THREE OR SIX MONTHS

DETAILED PROSPECTUS ON APPLICATION

READING ROOM FOR SUBSCRIBERS

NEW BOOKS ADDED IMMEDIATELY ON PUBLICATION 